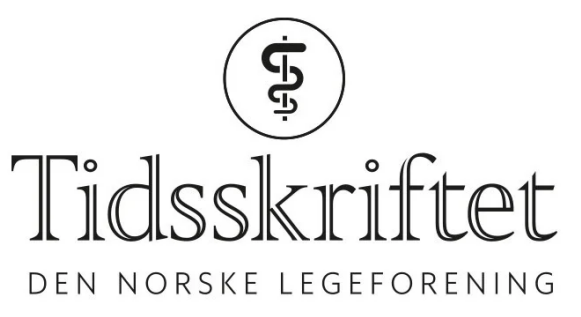

\title{
Alt hva menneskene klarer
}

INTERVJU

ANNE KATHRINE SEBJØRNSEN

Email: annekaths@hotmail.com

BUP Nordstrand

Forsvarets sjefpsykiater Jon Reichelt er bare måtelig opptatt av posttraumatisk stress og de psykiske belastningene soldater utsettes for når de deltar i krigshandlinger. Etter 13 år som psykiater i Forsvaret er det tvert imot fascinasjonen over menneskenes robusthet som fyller tankene. - Jeg lever av det som går galt, men min lodd i livet er blitt å forfekte det som faktisk går bra, sier han. 


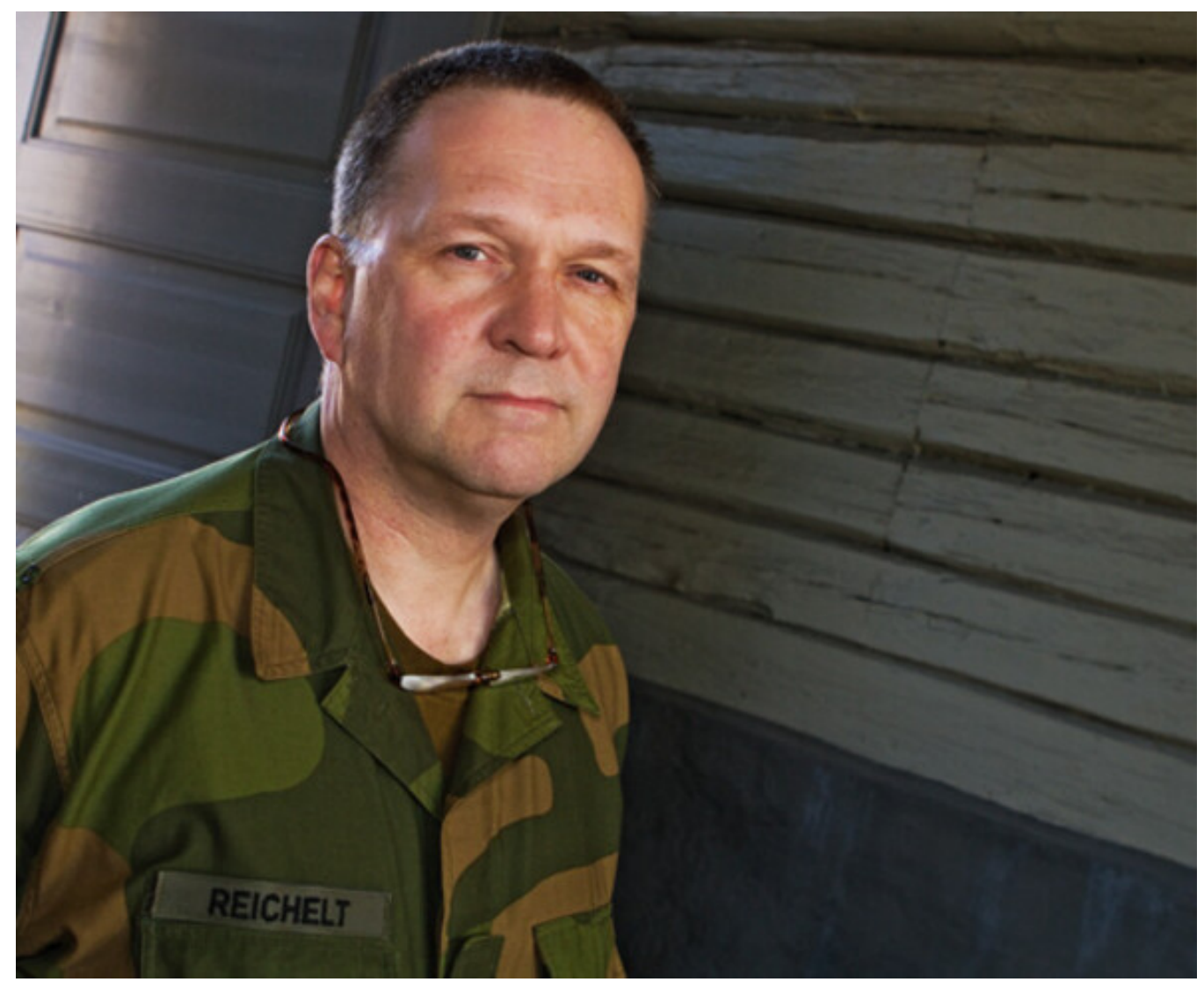

Foto Einar Nilsen

På underlig vis kommer jeg meg uhindret inn i et staselig forsvarsbygg det ikke skulle være mulig å entre uten klarering. Ærbødig passerer jeg Hans Majestet Kong Harald og Hennes Majestet Dronning Sonja som stirrer litt skeptisk mot meg fra veggen, før jeg i øverste etasje finner helsetjenesten. Jeg befinner meg i trappen da Jon Reichelts 194 centimeter og 100 kilo muskelmasse, opparbeidet ved aerobics på Friskis \& Svettis åpenbarer seg i døren. Han geleider meg inn til et kvistværelse og lener seg tilbake i en stol det knapt er plass til, da kontoret er fylt til randen av bøker. Her finnes faglitteratur om alt fra kognitiv terapi til ledelsesteori, og innimellom noen skjønnlitterære bøker. Jon Reichelt har ryddet plass til et intervju på ettermiddagen, for på dagen gjør han det han mener han er best til: å gå på skolen.

- Jeg tror folk gjør det de er gode på, og jeg er god til å gå på skolen. Det har jeg gjort i fryktelig mange år, men dette er nok den siste skolen jeg går på, sier han om det prestisjetunge sjefskurset på Forsvarets høgskole, der han kollokverer med både stortingspolitikere og næringslivstopper.- Det er interessant å møte folk med annen bakgrunn. Vi blir så innstilt på det vi driver med, og tror at sannheten finnes der. Jeg blir stadig mer ydmyk overfor alt hva vi ikke vet og kan. Som fagmann er det lett å tenke at alle er syke og trenger hjelp, men slik er det heldigvis ikke.

- Du kartla i Afghanistan-undersøkelsen 2012 den psykiske helsetilstanden til norsk militært personell som har tjenestegjort i Afghanistan i perioden 2001-11. Hva fant du ut?

- Det mest overraskende er kanskje at så mange som $95 \%$ av de militære klarer seg bra, uten noe behov for helsehjelp etter deltakelse i krigshandlinger. Det er altså bare et lite mindretall som vil trenge profesjonell hjelp.

- Er ikke det rart?

- Jeg er ikke så veldig overrasket. Da jeg tilfeldigvis havnet som psykiater på Radiumhospitalet, lærte jeg at de fleste mennesker klarer seg utmerket godt uten psykiatrisk bistand. 
Den gode psykiske soldathelsen kan kanskje tilskrives Forsvarets gode psykiatritilbud. Reichelt leder drøyt зo psykiatere og kliniske psykologer. Dagliglivet er lite rutinepreget, men innebærer stadig nye utfordringer og mye variasjon i arbeidet.

- Vi har ansvaret for soldatenes psykiske helse før, under og etter tjeneste. Vi bistår med seleksjon, undervisning, konsultative oppgaver, rådgivning og sakkyndighet.

\section{Don't worry, be happy!}

Jon Reichelt vokste opp med en far som hadde sittet i fangeleir i Hongkong under den annen verdenskrig og som tegnet et positivt bilde av militæret og legeyrket. Han var dessuten en entusiastisk reservelege i Forsvaret, og med tiden skulle han også vise seg å bli over gjennomsnittlig opptatt av peptider. Den unge gymnasiasten Jon, derimot, hadde som eneste ambisjon åunngå å bli lege. «Opprøret» varte i tre år, mens han leste litt psykologi, ferierte og ferierte mer, arbeidet litt som assistent på sykehus og ferierte enda litt mer. Erfaringene på sykehus pirret ikke nysgjerrigheten når det gjaldt å forstå sykdom, men derimot forekom det ham underlig at de fleste faktisk var friske, når det tross alt var så mye som kunne gå galt. Den undringen har fulgt ham siden.

- Har du funnet den magiske formelen til god helse?

- Ja, på en måte har jeg nok fått en forståelse av hvilke faktorer som gir grunnlag for å ha en god mental helse ved å studere hva som kjennetegner dem som kommer godt ut av de samme erfaringene som gir varige plager hos andre.

- Hvem er disse menneskene som klarer seg gjennom store belastninger?

- Forsvaret er en spennende arbeidsplass fordi jeg møter mennesker som er utstyrt med disse egenskapene fra naturens side, blant annet soldater i spesialstyrkene. Fellestrekkene er nok at de bekymrer seg lite, at de liker en utfordring, og at de ser på det meste i livet som en utfordring de kan mestre. De tar kontroll over det de kan kontrollere, resten overlater de til Gud eller skjebnen. De aksepterer litt risiko, og har det veldig bra underveis.

- Vi som ikke er født med denne avslappede livsholdningen, kan vi lære av dem?

- Ja, absolutt! Denne tankegangen er direkte overførbar til resten av livet, og det burde vi i større grad tenke på, for det er så lett å havne i grøfta. Mye av dette er medfødt, men vi kan øve oss opp til å tenke annerledes. Jeg ser at disse teknikkene virker på folk som strever, det å mestre noe man er redd for. Mennesker med angst sjekker at heisen er i orden før de går inn, noe de nok burde overlate til heiskontrollørene. Hvordan vi takler stress sitter jo også mellom ørene. Folk som får til ting, har gjerne måter å tenke på som vi kan lære noe av. I Forsvaret bruker vi lærdommen fra dem som holder seg friske til å hjelpe dem som strever til å få et bedre liv.

- Kognitiv terapi?

- Korrekt. Jeg er opptatt av kognitiv terapi, fordi det er en god modell for forebygging som selv svært praktisk orienterte soldater skjønner og bruker. I all enkelhet kan man si at dine tanker og handlinger, som du både kan trene og har en viss kontroll på, vil hjelpe deg til å mestre stress og følelser.

\section{Miner i grøftekanten}

- Men i $5 \%$ av tilfellene går det altså galt likevel. Hvorfor det?

- Det noen soldater gjør feil når de kommer hjem, er at de fortsetter å oppføre seg som om de er i krigen.

- De er på vakt? 
- Ja, de er redd for å tråkke på miner i grøftekanten eller å kjøre over bomber i veibanen. De fleste legger bort dette på flyplassen, men noen få tenker at det kan være lurt å passe seg også når de kommer hjem. Når det aldri går av noen bomber, får de det for seg at strategien deres virker, og de er på vei inn i en livsfarlig spiral. Etter en skremmende opplevelse er det naturlig å ha slike reaksjoner i starten. Men når det vedvarer, blir verden et umulig sted å oppholde seg. Dette er i utgangspunktet normale reaksjoner som bunner i at det er viktig å lære av dramatiske situasjoner, men soldatene skaffer seg selv et kjempestort problem når det fortsetter, og de kjører seg inn i et negativt spor. Det kan være en smertefull prosess å trene seg ut av det, men nesten alle klarer det hvis de er motivert. Samtidig opplever de fleste en enorm lettelse når de blir kvitt angsten, det gjør jo livet levelig igjen.

- Hvordan hjelper du dem?

- Eksponeringsterapi virker! Et godt utgangspunkt kan være å snakke sammen om sannsynligheten for at de skal oppleve noe slikt her, for eksempel at det er ekstremt sjelden det går av bomber i Norge. En ekssoldat syklet aldri på sykkelstien, bare på hovedveien, fordi der hadde andre kjørt før ham og sannsynligheten for en bombe var lav. Han hadde erfart at verden var farlig, og hadde våpen hjemme for sikkerhets skyld. Da ble verden ekstremt farlig. Redsel fører til at man forsøker å ta kontroll, og man må veie risiko mot hvilket tap det vil innebære ikke å kunne være utendørs. Motivasjon er helt sentralt, for eksempel vil det ikke være mulig å trene seg ut av flyskrekk hvis man fortsetter å tro at det er $10 \%$ fare for at flyet vil dette ned. De fleste er derimot villige til å akseptere en lav risiko.

- Hvordan er risikoen som soldat i Forsvaret?

- Forsvaret har endret seg enormt de siste 15 årene, spesielt på grunn av Afghanistan. Nå er det svært profesjonalisert, og det preges av et alvor som ikke var der på samme måte tidligere. Dette handler om unge mennesker som skal ut i krig, og det deles ikke ut andreplasser. Det er med livet som innsats man verver seg til tjeneste.

- Hvordan trener dere vekk frykt for miner og bomber?

- Vi er ute og eksponerer i Oslos gater. Vi går barføtt på gresset og i grøftekantene, kjører bil som førstemann på hovedveien om morgenen.

- Hva har de opplevd, de som blir så redde?

- Det varierer veldig. Noen har opplevd dramatiske situasjoner, men mange har bare hørt om farlige situasjoner eller vært på vakt. Den utløsende hendelsen kan være relativt udramatisk for personen selv, som at det har gått av en bilbombe i Kabul, på en vei de selv har kjørt mange ganger, men uten at de selv har hatt noen befatning med selve hendelsen.

- Hva er ditt beste helseråd til militært personell?

- Det er helt klart å akseptere at du er dødelig, men at det er lite å gjøre med uflaks. Litt risiko må man være villig til å akseptere om man skal få det ut av livet som man ønsker!

\section{Østkantgutt og såpeoperaelsker}

For en psykiater som daglig håndterer andres vansker, er det viktig å finne avkobling som innebærer litt «egenterapi». Jon Reichelt er opptatt av humor, gjerne lett upassende og svart. Han er sannsynligvis en av få leger som trekker frem sin hang til amerikanske dramaserier, gjerne av sorten såpeserie, som fritidsinteresse.

- Humor er ekstremt viktig for overlevelse! Du må gjerne ta med det om såpeseriene i intervjuet. Jeg skammer meg ikke over det, sier han og unnskylder seg med at Dr. House innerst inne har en agenda om å hjelpe pasientene sine, selv om han nok ikke er noe eksempel til etterfølgelse. 
Når han ikke er på jobb for Forsvaret, er Jon Reichelt først og fremst familiemann. Han er ihuga østkantgutt. Store deler av oppveksten tilbrakte han i Oslo øst, nærmere bestemt Prinsdal. Selv mener han det har ført til en identitet som østkantgutt og varig sans for mangfold, og en klart redusert trang til hva mange vil kalle en korrekt og passende adresse.

- I dag holder jeg til på Mortensrud - i et virkelig kulturelt mangfold av mennesker som klarer seg riktig så bra, og stort sett selv!

Barna er ute av redet, og han og hans kone har skaffet seg en litt uoppdragen hund for å døyve stillheten.

- Det sies jo at man skaffer seg en hund som likner en selv. Jeg har altså en flat coated retriever som likner meg en god del. Den er entusiastisk, aktiv og litt rampete, men stort sett snill og grei.

\section{Jon Reichelt}

Født 1961

- Cand.med. Universitetet i Oslo1989

- Spesialist i psykiatri 1998

- Ansatt i Forsvaret siden 2000

- Sjef for Forsvarets psykiatri siden 2007, oberstløytnant

- Dr.med. i 2008 på et arbeid om de psykiske reaksjoner ved tilbud om genetisk testing for arvelig bryst- og eggstokkreft

- Utdannet kognitiv terapeut ved Nasjonalt institutt for kognitiv terapi (NIKT)

- Master of management fra BI i 2012

- Sjefskurset ved Forsvarets høgskole våren 2013

Publisert: 11. juni 2013. Tidsskr Nor Legeforen. DOI: 10.4045/tidsskr.13.0552

(C) Tidsskrift for Den norske legeforening 2023. Lastet ned fra tidsskriftet.no 26. april 2023. 